\title{
State Exclusivity of Fisheries Resources on Exclusive Economic Zone in Efforts to Support the Fisheries Availability as a Means of Increasing Food Security for the State
}

\author{
*Belardo Prasetya Mega Jaya \\ Department of Law Faculty \\ Sultan Ageng Tirtayasa University \\ Banten, Indonesia \\ *belardoprasetya@gmail.com
}

\author{
Afandi Sitamala \\ Department of Law Faculty \\ Sultan Ageng Tirtayasa University \\ Banten, Indonesia \\ asitamala@untirta.ac.id
}

\author{
Danial \\ Department of Law Faculty \\ Sultan Ageng Tirtayasa University \\ Banten, Indonesia \\ bontobangun@gmail.com
}

\begin{abstract}
Based on United Nations Convention on the Law of the Sea 1982 (UNCLOS 1982), Indonesia has sovereignty in the Indonesian waters and has exclusive rights in natural resources utilization in the Exclusive Economic Zone (EEZ). By having sovereignty in the Indonesian waters and exclusive rights in the EEZ, Indonesia should be able to exploit this potential to optimize the fisheries availability as a means of increasing food security for the state, but in reality, the fisheries availability cannot be optimized because of many IUU-Fishing practices which has an impact on decreasing food security. Therefore, the aims of the research are: (1) to describe and explain how to overcome and eradicate IUUFishing in Indonesian exclusive economic zone. (2) to describe and explain how is the solution to apply the state exclusivity principle of fisheries resources optimally in efforts to support the fisheries availability as a means of increasing food security for the state. This research used normative legal research. The results of the research shows that in overcoming and eradicating IUU-Fishing in Indonesian EEZ preventive and repressive measures must be taken. To optimize state exclusivity of fisheries resources in Indonesian EEZ as a means of increasing food security, a good fisheries management is needed, namely the Republic of Indonesia Fisheries Management Area. The Indonesian government must also improve facilities and infrastructure for fisheries supervisors or enforcers and improve surveillance operations in EEZ. In addition, Indonesia also should make bilateral or multilateral cooperation mechanisms with states with opposite or adjacent coasts.
\end{abstract}

Keywords: State Exclusivity of Fisheries, Increasing Food Security, Fisheries Resources, Fisheries Management Area

\section{INTRODUCTION}

The Republic of Indonesia is one of the largest countries in the world with a total area of $5,193,250 \mathrm{~km}^{2}$ (including oceans and land) [4]. This positioned Indonesia as the 7th largest country in the world after Russia, Canada, the United States, China, Brazil, and Australia. Indonesia also is the $2^{\text {nd }}$ largest country in Asia and the largest country in Southeast Asia. The area of Indonesia's oceans is greater than it's land area, which is one-third of the area of Indonesia island and two-thirds of Indonesia's area is sea [5]. With the ratification of the 1982 United Nations Convention on the Law of the Sea (UNCLOS), the territory of Indonesia has become wider, namely $8,193,250 \mathrm{~km}^{2}$ consisting of $2,027,087 \mathrm{~km}^{2}$ of land and $6,166,165 . \mathrm{km}^{2}$ of territorial waters. Indonesian marine waters have a beach length of up to $95,181 \mathrm{~km}^{2}$, with an area of waters of 5.8 million $\mathrm{km}^{2}$ consisting of territorial sea covering an area of 0.3 million $\mathrm{km}$, archipelago waters with an area of 2.8 million $\mathrm{km}^{2}$, and waters of the Exclusive Economic Zone (EEZ) with an area of 2.7 million $\mathrm{km}^{2}$ [6].

Indonesia has been recognized in the UNCLOS 1982 as an archipelagic country [7] that has a full and wide sea, because as an archipelagic state Indonesia can draw baselines from the outer points of the islands the outermost (the outermost point of the outermost islands ad drying reefs) [8]. According to UNCLOS 1982, Indonesia has sovereignty in the territorial waters of Indonesia and has exclusive rights in the use of natural resources in the region of Indonesian Exclusive Economic Zone (IEEZ).

The EEZ region has a sui generis (unique/different) legal status. Different if in territorial sea, coastal countries have sovereignty, in EEZ coastal countries only have sovereign rights, which are limited to the exploration and exploitation of marine resources both biological and non-biological resources [9]. Coastal countries have exclusive rights for the purposes of exploration, exploitation, conservation, and management of natural resources, both biological and nonbiological, from waters on the seabed and from the seabed and underlying land and with regard to other activities for the purposes of exploration and economic exploitation in the zone exclusive economy.

By having sovereignty over exploration and exploitation of natural resources in the Indonesian waters and exclusive rights in the EEZ region, Indonesia should be able to exploit this potential to optimize the availability of fish as a means of increasing food security. However, in reality, Indonesia has not been able to optimally utilize these exclusive rights and the good potential has led to many Illegal, Unreported and Unregulated-Fishing (IUU-Fishing) practices. The factor causing IUU-fishing in IEEZ is due to a legal loophole regulated in the provisions of Article 29 of Law Number 31 Year 2004 concerning Fisheries which states that a foreign person or legal entity can enter IEEZ region to conduct fishing efforts based on international agreements or provisions of applicable international law and based on Indonesian national legislation [10]. 
This is in accordance with the provisions of Article 62 UNCLOS 1982, which states that coastal states were obliged to grant access rights to other countries to exploit biological wealth in the EEZ region if the coastal State does not have the ability to utilize the entire amount of catch that can be allowed, but the state granted the opportunity must be a criterion for a landless state or a geographically disadvantaged country in accordance with Articles 69 and 70 UNCLOS 1982 [11]. The article seems to provide opportunities for foreign fishermen to enter the IEEZ for then explore and exploit biodiversity in IEEZ region. Thus, in fact, these exclusive rights are not maximally obtained because so many other countries have participated in exploring and exploiting natural resources in IEEZ without prior agreement and the country is not a country that is allowed to get access rights to explore and exploiting the source of wealth in IEEZ, which is a land-lock States or geographically disadvantaged States.

In addition, in reality many practices also occur IUUFishing because foreign fishing vessels that enjoy access rights to IEEZ do not comply with Indonesian national legislation, which can contain obligations and requirements such as permits, financial rewards, quotas, conservation actions, information, research, observers, catch landings, cooperation agreements, and so on [12]. The crossing position of Indonesia which is located between two oceans (Pacific and Indian) and two continents (Asia and Australia) is also the cause of Indonesia's territory being prone to the practice of IUU-Fishing [13]. The frequent occurrence of IUU-Fishing practices is certainly very detrimental to Indonesia, both in the economic, ecological, and social fields.

Indonesia's President, Joko Widodo stated that IUUFishing has caused Indonesia's economic loss of 20 billion US dollars per year and threatened 65 percent of coral reefs [14]. The amount of loss is an amount that is not small. In addition, the practice of IUU-Fishing also has an impact on decreasing stock of fish resources and loss of social and economic opportunities for fishermen who operate legally, as well as resulting in decreased food security [15]. Therefore, a study is needed to provide a solution to overcome and eradicate IUU-Fishing in IEEZ as well as solutions on how to optimize the exclusivity rights of the State's fisheries resources in the EEZ.

With this research, new findings or policies will be produced so that they can be useful and provide solutions for the Government to overcome and eradicate IUU-Fishing in IEEZ and the Government of Indonesia is able to optimize the exclusive rights of Indonesian fisheries resources in EEZ. Optimal use of the exclusive rights of the country's natural resources in the EEZ, will have an impact on the progress of the Indonesian economy, national development, and be able to improve food security for the country. The findings or new policies in this study can also be used as a role model for other countries to be able to also overcome and eradicate IUU-Fishing and optimize the right to exclusivity of the country's fisheries resources in the EEZ.

\section{RESULT AND ANALYSIS}

\section{A. Eradication of IUU-Fishing in Indonesia's Exclusive Economic Zone}

Indonesia as an archipelagic country is the country with the largest and most archipelago consisting of 17,508 islands with $81,000 \mathrm{~km}$ of coastline and an area of around 3.1 million $\mathrm{km} 2$ (0.3 million $\mathrm{km} 2$ of territorial waters and 2.8 million $\mathrm{km} 2$ of archipelago waters) or $62 \%$ of its territorial area. 16 With these vast waters making Indonesia a country rich in marine and fish resources.17 In fact, this abundant wealth actually causes many IUU-Fishing practices carried out by ships from other countries (foreign vessels).

Discourse about IUU-fishing emerged together in the framework of Illegal, Unreported, Unregulated Fishing Practices when the CCAMLR (Commission for Conservation of Atlantic Marine Living Resources [19]) was held on 27 October-7 November 1997. From this forum then the IUU-Fishing issue This was made a major issue at the global level by the Food and Agriculture Organization (FAO) with a strong reason, that currently the world's fish reserves are showing a declining trend and one of the factors is the practice of IUU-fishing in the territorial sea, inland waters, inland waters or in exclusive economic zone [20].

The most common illegal fishing activity in WPP-RI is the theft of fish by foreign flagged fishing vessels, especially from several neighboring countries.[21]. The forms of IUUFishing activities that generally occur in Indonesian territorial waters include: [22] (1) fishing without permission, (2) fishing using fake permits, (3) fishing using prohibited fishing gear, (4) catching fish that do not match the catchment area stated in the fishing permit. As explained earlier, the number of IUU-Fishing practices is very detrimental to Indonesia, both in the economic, ecological, and social fields, so it is fitting for IUU-Fishing to be eradicated so that the availability of fishery resource stocks can remain abundant and can be utilized optimally as a means of increasing resilience state food.

In combating IUU-Fishing, it takes preventive and repressive measures. Prevention can be done with prevention in legal aspects and technical aspects [23]. Related to legal aspects, the Government must pay attention to the following matters [24]:

\section{a) Ship Registration}

Every ship sailing in Indonesia must register its ship. Foreign ships were flagged ships other than the Indonesian flag and were not recorded in the list of Indonesian ships. Therefore, the absence of vessel registration makes it difficult to record and monitor the activities of foreign vessels and it is difficult to distinguish which foreign fishing vessels are legal and which are illegal fishing vessels. For this reason, national legislation must immediately regulate the issue of licensing of foreign fishing vessels operating in IEEZ [25].

\section{b) Ship Licensing}

In relation to fishing business activities, foreign vessels must first obtain a permit from the Indonesian state that has jurisdiction or authority in its territory. According to Law Number 45 of 2009 concerning Fisheries, every vessel with a foreign flag must have [26]: (1) Fishery Business License 
(SIUP) [27]; (2) Fishing Permit (SIPI) [28]; (3) Fish Transport Vessel License (SIKPI) [29]. Requirements and procedures for obtaining SIUP, SIPI, and SIKPI for fishing vessels and fish-carrying vessels carrying out activities in WPP-RI are regulated in the Minister of Maritime Affairs and Fisheries Number PER.49/MEN/2011 concerning Capture Fisheries Business; (4) Operational eligibility, [30]; (5) Sailing Approval Letter [31]. In carrying out their duties, the Shahbandar at the fishing port is coordinated by the official in charge at the local fishing port [32]. A new Sailing Agreement will be issued by the Shahbandar after the fishing vessel has obtained an operation-worthy certificate [33].

\section{c) Surveillance}

Increasing security in the Indonesian waters and IEEZ which covers an area of 6 million $\mathrm{km} 2$ still requires great attention, including security in the Indonesian Archipelago Sea Lanes (ALKI). This increased security includes close collaboration between activities on land, sea, and air. Efforts to improve monitoring, control, surveillance, and investigative activities must be arranged as well as possible [34]. Fisheries Oversight is an activity aimed at ensuring an orderly implementation of the provisions of the laws in the field of fisheries [35]. The fishery control vessel functions to carry out supervision and law enforcement in the field of fisheries in the territory of the Republic of Indonesia fisheries management (WPP-RI) where the fishery control vessel can be equipped with firearms [36].

Discussing illegal fishing cannot be separated from the structure of law enforcement at sea, namely agencies and law enforcement officers at sea in anticipating and overcoming problems in law enforcement. In addition, law enforcement must also be assisted by parties in the area in handling the IUU-Fishing case conducted by foreign fishing vessels. President of the Republic of Indonesia Joko Widodo has issued a Presidential Regulation (Pepres) concerning the IUU-Fishing Eradication Task Force. Pepres No. 115 of 2015 concerning the Task Force on Combating Illegal Fishing. Article 2 of this Presidential Decree states that the Task Force is tasked with developing and carrying out law enforcement operations in an effort to eradicate illegal fishing in the territorial jurisdiction of Indonesia effectively and efficiently by optimizing the utilization of operational personnel and equipment, including ships, aircraft, and other technologies owned by The Ministry of Maritime Affairs and Fisheries, the Indonesian National Navy, the Indonesian National Police, the Attorney General's Office of the Republic of Indonesia, the Maritime Security Agency, the Special Task Force for Upstream Oil and Gas Business Activities, PT. Pertamina and other related institutions [37].

The collaboration between the Ministry of Maritime Affairs and Fisheries with other agencies is useful for promoting stability in maritime surveillance and law enforcement at sea. In one institution, especially in the regions, of course, do not have all the components, data/information or facilities, and infrastructure needed in the context of law enforcement. Therefore we need synergic coordination and cooperation between agencies involved in law enforcement efforts against the IUU-Fishing [38]. In order that law enforcement runs well, and is more effective, coordinated between the agencies/officials of the Ministry of Maritime Affairs and Fisheries with other agencies can coordinate with each other by forming a coordination forum as mandated in Article 73 paragraph (3) of the Fisheries Act [39]. The forum was formed through the Minister of Maritime Affairs and Fisheries Regulation No. Per.18 / Men / 2011 concerning the Coordination Forum on Criminal Acts in the Field of Fisheries. The regulation is an implementing regulation of Article 73 paragraph (1) of the Fisheries Law. This forum is tasked with coordinating all investigative activities in the field of fisheries, synchronizing and coordinating the activities of handling criminal offenses in the field of fisheries carried out by each of the relevant agencies so that they are effective, efficient, and fulfill a sense of justice [40].

In addition to the importance of the legal aspects above, in preventing the practice of IUU-Fishing, the Indonesian Government must also pay attention to the technical aspects. The technical aspects include [43]:

\section{a) Improvement of facilities and infrastructure in} supervision

Supervision is an activity that is very important so that regulations can run according to their objectives. In terms of supervision, adequate facilities and infrastructure are needed so that supervision can run well and smoothly. The availability of monitoring facilities and infrastructure in EEZ in large numbers for the eradication of IUU-Fishing is very important considering the vast extent of EEZ Indonesia that must be monitored. Facilities and supervision infrastructure needed to eradicate IUU-Fishing include [44]: Need to improve the Technical Implementation Unit (UPT) of Supervision in areas prone to IUU-Fishing; The need for additional surveillance ships/patrol vessels so that supervision can run effectively; Vessel Monitoring Systems (VMS) installation is required as recommended by FAO. Simply put, this system consists of a database system based on a geographic information system (GIS) so that VMS operators can monitor all ship positions in a particular water area.

Thus the presence of foreign fishing vessels can be immediately identified so that further action can be taken; Air patrol aircraft, so that they are not only monitored or monitored from the sea; Beach radar; Firearms as a safety device or in self-defense.

\section{b) Improved Supervision Operations}

In addition to improving the facilities and infrastructure for fisheries supervision, supervision operations should also be improved so that supervision can run well. The supervision program can be carried out through: Increased vessel compliance operations at fishing port ports; Increased operations by supervisory vessels, through the addition of operating hours in areas that become fishing ground or areas/areas prone to IUU-fishing by foreign fishing vessels; Increasing the observer program on fishing vessels; Increasing the national fishing fleet, so that foreign ships will be reluctant to do IUU-Fishing; Enhancing synergic cooperation between law enforcement officials The Department of Maritime and Fisheries Cooperation with other agencies is useful to establish stability in the supervision of marine services, the creation of strong coordination in the supervision of marine services and the Office of Maritime Affairs and Fisheries and related agencies [45]. 
c) Increased IUU-fishing cooperation with neighboring countries

The program of increasing cooperation in countering IUU-Fishing with neighboring countries will greatly assist in suppressing the eradication of IUU-Fishing. The perpetrators of IUU-Fishing themselves come from neighboring countries. Therefore, we need cooperation that helps each other to eradicate the IUU-Fishing.

d) Improved Community-Based Supervision System (SISWASMAS)

Improving the community-based supervision system needs to be an alternative in the prevention and control of IUU-Fishing. Based on Law Number 45 of 2009 concerning Fisheries and Decree of the Minister of Maritime Affairs and Fisheries Number KEP.58/MEN/2001 concerning Procedures for Implementing Community Monitoring Systems in the Management and Utilization of Resources Maritime Affairs and Fisheries, fisheries supervision can involve the community. Related to this, the Ministry of Maritime Affairs and Fisheries has developed a Communitybased Monitoring System (SISWASMAS) by involving the Community Monitoring Group (POKMASWAS). In other words, Indonesian fishermen watch the sea or can be used as a "spy" in the sea against foreign vessels. In addition to the above preventive measures, in eradicating IUU-Fishing, it is needed. Also, repressive actions or actions after violations occur. The repressive actions are as follows:

\section{a) Law Enforcement through Fisheries Court}

In relation to the enforcement of fisheries business law, it is necessary to establish a judicial institution to support law enforcement in the field of fisheries concerned [46]. Law enforcement carried out by fisheries oversight agencies is limited in the scope of the pursuit, arrest, investigation and case investigation which are then submitted to the Prosecutor's Office. A fisheries court is formed which has the authority to examine, hear, and decide on criminal acts in the fishery sector [47]. The fishery court is a special court within the general court environment and is domiciled in a district court.

For the first time, the fisheries court was established in North Jakarta District Court, Bitung District Court (North Sulawesi), Medan District Court, Pontianak District Court, and Tual District Court (Maluku) [48]. The role of the fisheries court is very much needed, because of the glimpse of the IUU-Fishing case that occurred in the Indonesia waters conducted by ships/foreign nationals. Therefore, the fisheries court is also authorized to hear, examine, and decide criminal action cases in the field of fisheries committed by foreign nationals in the territory of WPP-RI [49].

\section{b) Strict Sanctions}

The existence of a sanction is an effective means to reduce the occurrence of violations in the field of fisheries. Initially, sanctions that were imposed in Law 31 of 2004 concerning Fisheries was only in the form of administrative sanctions, fines, and prison sentences, but Law Number 31 of 2004 concerning Fisheries was still unable to eradicate or reduce the case of IUU-Fishing. The law still has many weaknesses, especially in the completeness of the rules and also there are no severe sanctions, so the law is considered insufficient to overcome the problem of IUU-Fishing.
Law Number 45 of 2009 complements the provisions of Law Number 31 of 2004 concerning Fisheries, one of which is to regulate law enforcement for IUU-Fishing perpetrators in Indonesia. Through Law Number 45 of 2009, Indonesia has begun to take decisive action in law enforcement against foreign vessels conducting IUU-Fishing in Indonesian territorial waters, namely by carrying out acts of burning and / or sinking foreign vessels based on sufficient preliminary evidence. The action was taken so that law enforcement in Indonesia is firm and effective so that foreign fishermen have a deterrent effect to no longer catch fish illegally.

In the EEZ, if foreign vessels do not comply with the rules of the fishery in Indonesia, Indonesia can arrest, detain and process their captain and crew. This is in accordance with the provisions of Article 73 of UNCLOS 1982. However, the punishment of the foreign ship cannot be in the form of a body sentence which is custody [50]. The captured vessel and crew must be released immediately after paying a reasonable bond given to the coastal country. With punishment in the form of a proper security deposit, the coastal state will receive adequate compensation for the fishery resources that have been stolen. The deposit must meet the element of eligibility or must be adjusted to the size or value of the ship/price of the ship, fuel, lubricants, fish caught and fishing equipment as stipulated in the International Tribunal for the Law of the Sea (ITLOS) [51]. If the perpetrators are unable or unwilling to pay a reasonable bound, then there is no choice, Indonesia will continue to hold the crew and burn and / or sink the ship.

If a foreign ship is about to be inspected, but the foreign vessel refuses to be inspected and even escaped, Indonesia (fisheries investigators) can conduct an instant pursuit (Right of hot pursuit) of the foreign ship. This is regulated in Article 111 UNCLOS 1982. Instant pursuit of a foreign ship can be carried out if the competent authority of the coastal State has sufficient reason to think that the ship has violated the laws and regulations of that State. [52].

Law enforcement actions implemented by Indonesia are carried out so that law enforcement in Indonesia is firm and effective. This is in accordance with the provisions of the Code of Conduct for Responsible Fisheries (CCRF). According to the CCRF, countries and all parties involved in fisheries management, through an appropriate legal and institutional policy framework, must adopt long-term conservation measures and sustainable use of fisheries resources [53]. In implementing the CCRF, countries must ensure the establishment of an effective legal and administrative framework both at the regional and national/central levels for the conservation of fish resources and fisheries management [54]. Countries in accordance with the laws and regulations must implement effective law enforcement or guarantee legislation that contains sanctions commensurate with the severity of the violation [55].

In addition, strict action in law enforcement by Indonesia is also based on the formulation of an international action plan to combat IUU-Fishing as outlined in the International Plan of Action to Prevent, Deter and Eliminate IUU Fishing (IPOA IUU-Fishing). According to IPOA-IUU Fishing, countries must pay attention to their respective national legislation. National legislation contains effective rules for all aspects [56]. Countries must guarantee severe sanctions 
against IUU Fishing vessels in their jurisdiction so that they can effectively prevent, reduce and eliminate IUU Fishing, and prevent perpetrators from profiting [57]. IPOA-IUU Fishing follow up to the national action plan has been carried out by several countries, one of which is Indonesia through the Decree of the Minister of Maritime Affairs and Fisheries Number KEP / 50 / MEN / 2012 concerning the National Action Plan for Prevention and Control of IUU-Fishing in 2012-2016. Therefore, Indonesia has set strict laws and sanctions on IUU-fishing vessels [58].

\section{B. Optimizing the Exclusive Rights of Indonesian Fisheries Resources in EEZ as a Food Security Facility}

Clearly, Exclusive Economic Zone according to Article 55 of UNCLOS 1982 can be interpreted as a sea lane located outside and adjacent to its territorial sea, which is subject to a special legal regime regulated in Chapter V of the Law of the Sea Convention 1982. Based on the provisions of Article 57 of UNCLOS 1982 that each coastal State has the right to determine the EEZ, the distance of which must not exceed 200 nautical miles measured from the same baseline used to measure the width of the territorial sea [59].

In short, 200 miles are sovereign rights for the coastal State to natural resources in EEZ including fisheries. With the ratification of the legal regime of the Exclusive Economic Zone within the scope of the International Law of the Sea, the fisheries resources of the Indonesian people will increase in number and play a very potential role. It is also known that Indonesia is a maritime country which has an Indonesian Exclusive Economic Zone area of approximately 2,692,762 km2 [60]. With the vast Indonesian Exclusive Economic Zone, Indonesia as a coastal country should be maximally utilized by Indonesia to support an increase in fish stocks optimally as a means of increasing food security for the country.

To optimize the exclusive rights of Indonesian fisheries resources in ZEEI as a means of increasing food security, a good fisheries management is needed, which is an activity to take care of or carry out something related to catching, maintaining, and cultivating fish [61]. According to Law Number 45 of 2009 concerning Fisheries, fisheries management is all efforts, including an integrated process in gathering information, analysis, planning, consultation, decision making, allocation of fish resources, and implementation and law enforcement of laws and regulations in in the field of fisheries, which is carried out by the government or other authorities directed at achieving sustainable productivity of aquatic resources and agreed upon.

The acknowledgment of the formulation is very broad so that it can accommodate all fisheries issues both technical and non-technical in nature because it is a unified whole in fisheries management. In addition, the formulation of the formula is intended so that fisheries management can be carried out better and more professionally and can acquire results with greater benefits [62]. $\mathrm{n}$ order to support this, the Republic of Indonesia Fisheries Management Area (WPP-RI) [63]. was established. WPP-RI is a fisheries management area for fishing, fish cultivation, conservation, research, and fisheries development which includes inland waters, inland waters, territorial sea, additional zones, and Indonesia EEZ [64].

Based on the Minister of Maritime Affairs and Fisheries Regulation No.01 / MEN / 2009 concerning the Fisheries Management Area of the Republic of Indonesia with reference to the standards of the Food and Agriculture Organization (FAO), the distribution of WPPs into 11 WPPs is determined, namely:

1) WPP-RI 571 covers the waters of the Malacca Strait and the Andaman Sea;

2) WPP-RI 572 covers the waters of the Indian Ocean to the west of Sumatra and the Sunda Strait;

3) WPP-RI 573 covers the waters of the Indian Ocean south of Java to the south of Nusa Tenggara, the Savu Sea and the West Timor Sea;

4) WPP-RI 711 covers the waters of the Karimata Strait, the Natuna Sea, and the South China Sea;

5) WPP-RI 712 covers the waters of the Java Sea;

6) WPP-RI 713 covers Makassar Strait waters, Bone Bay, Flores Sea and Bali Sea;

7) WPP-RI 714 Covers the waters of the Tolo Bay and the Banda Sea;

8) WPP-RI 715 covers the waters of Tomini Bay, Maluku Sea, Halmahera Sea, Seram Sea and Berau Bay;

9) WPP-RI 716 covers the waters of the Sulawesi Sea and the northern part of Halmahera Island;

10) WPP-RI 717 includes the waters of the Cenderawasih Bay and the Pacific Ocean;

11) WPP-RI 718 covers the waters of the Aru Sea, Arafuru Sea and East Timor Sea.

With the existence of fisheries management areas for fishing, fish cultivation, conservation, research, and fisheries development, it is expected to be able to optimize the availability of fish and improve food security for the country. Based on Article 29 of the Fisheries Law, that fisheries in the Fisheries Management Area of the Republic of Indonesia may only be carried out by citizens of the Republic of Indonesia or Indonesian legal entities, except for foreign persons or legal entities that carry out fishing efforts in ZEEI, as long as it concerns liability the Republic of Indonesia based on international agreements or applicable international legal provisions [65].

Article 29 seems to provide opportunities for foreign fishermen to enter the EEZ Indonesia to then explore and exploit the biological wealth in the EEZ region of Indonesia. These provisions must be made clear that access rights can be granted when the coastal state does not have the ability to utilize the entire amount of the catch of biological resources that can be allowed by prior agreement, must obtain permission from the Indonesian government, and must comply with conservation measures and other requirements specified in the laws of the coastal states [66]. In addition, based on the 1982 UNCLOS obligation, those who get the opportunity to utilize the number of catches in accordance with the allowable number of catches remaining are landlock States and geographically disadvantaged states [67].

Therefore, in the implementation of granting access rights to use marine resources in ZEEI to foreign persons or 
legal entities, it requires effective control from the Government of Indonesia because in reality, many other countries have participated in exploring and exploiting marine resources in ZEEI without there is a prior agreement and the country is not a country that is allowed to get access rights in exploring and exploiting the source of wealth in EEZ, namely the land-lock States or land that is geographically disadvantaged. The vast extent of the EEZ region and the limited facilities and infrastructure owned by law enforcement officers have caused the implementation of law enforcement at sea to be optimally implemented which is able to protect the entire territory of Indonesia's Exclusive Economic Zone and impact on the many practices of IUUFishing. [68].

Therefore, as previously explained, the Indonesian government must improve facilities and infrastructure for fisheries supervisors or enforcers as well as increase oversight operations in each fisheries management area both in sovereignty areas and in EEZ so that they are able to supervise and protect fisheries management areas from any activities or illegal fishing business.

In addition, there is also a need for bilateral or multilateral cooperation mechanisms with States that are facing or side by side with Indonesia in EEZ to respect the sovereign rights of each State in EEZ, jointly eradicating IUU-Fishing, appealing strongly to all citizens to does not conduct IUU-Fishing business, and applies the optimal form of compensation for vessels conducting IUU-Fishing in EEZ of other countries.

\section{CONCLUSION}

As the aforementioned analysis, it can be concluded that:

1. In eradicating IUU-Fishing, preventive and repressive measures are needed. Preventive enforcement can be done with prevention in legal and technical aspects. Related to the legal aspects, the Government must pay attention to the following matters: Ship registration; Licensing of ships; and Supervision. In addition to the importance of the legal aspects above, in preventing the practice of IUU-Fishing, the Indonesian Government must also pay attention to the technical aspects. The technical aspects include Increased Supervision Operations; Enhancing cooperation in countering IUU-Fishing with neighboring countries; Increasing cooperation in overcoming IUU-Fishing with neighboring countries, while the repressive measures are as follows: Law Enforcement through the Fisheries Justice; Provide strict sanctions.

2. To optimize the exclusive rights of Indonesian fisheries resources in IZEE as a means of increasing food security, a good fisheries management is needed, namely the stipulation of the Fisheries Management Area of the Republic of Indonesia (WPP-RI) with reference to the standards of the Food and Agriculture Organization (FAO) which is divided into 11 WPP. The existence of the fisheries management area is expected to be able to optimize the availability of fish and increase food security for the country. The Indonesian government must also improve facilities and infrastructure for fisheries supervisors or enforcers as well as improve surveillance operations in EEZ. In addition, there is also a need for bilateral or multilateral cooperation mechanisms with States that are facing or side by side with
Indonesia in EEZ to respect the sovereign rights of each State in EEZ, jointly eradicating IUU-Fishing, appealing strongly to all citizens to does not conduct IUU-Fishing business, and applies the optimal form of compensation for vessels conducting IUU-Fishing in EEZ of other countries.

\section{REFERENCES}

[1] Dikdik Mohammad Sodik, 2014. International Law of the Sea and Regulations in Indonesia, Bandung: Refika Aditama.

[2] Eva Johan, 2012. International Law of the Sea (UNCLOS 1982), Serang: CV Cahaya Minolta.

[3] Ignatius Yogi Widianto Setyadi \& Bambang Riyanto, 2014. Indonesia's Efforts in Addressing the Illegal Fishing Problem in Indonesia's Exclusive Economic Zone, Yogyakarta: University of Atma Jaya.

[4] Rokhimin, 1996. Integrated Management of Coastal and Ocean Regional Resources, Jakarta: Pradnya Paramita, First Printing.

[5] Supriadi \& Alimudin, 2011. Fisheries Law in Indonesia, Palu: Sinar Grafika.

[6] Akhmad Solihin, 2008. Eradication of Illegal, Unreported and Unregulated (IUU) Fishing Under International Law and Its Implementation in National Legislation, thesis, Bandung: Padjadjaran University Bandung.

[7] Barracuda, 2005. "P2SDKP collaborates in the Supervision of Maritime Services". Volume II Nomor 2, August. I

[8] Belardo Prasetya Mega Jaya, 2018. "The Law Enforcement Towards Foreign Vessels Which did Illegal Fishing in Indonesia's Fisheries Management Areas", Fiat Justisia, 1st edition, Vol 1, Lampung.

[9] FAO, 2012. "Technical Guidelines For Responsible Fisheries, Implementation of The International Plan of Action to Prevent, Deter and Eliminate Illegal, Unreported and Unregulated Fishing", Fiat Panis.

[10] Heryandi, 2019. "Implementation of Indonesian Maritime Policy in the Autonomous Region", Aura Publishing, Lampung, ISBN: 978623-211-018-2.

[11] Marhaeni Siombo, 2009. The Influence of Fishermen's Counseling and Motivation Methods on Knowledge of Environmentally Friendly Fishing (Experiments on Fishermen at the Fish Auction Place (TPI) of Muara Angke, North Jakarta 2008), Synopsis of the Desert Masters Program, UNJ, Jakarta.

[12] Marudut Hutajulu, Alvi Syahrin, Mahmud Mulyadi, Marlina, 2014. "Criminal Law Analysis of illegal fishing in Indonesian Exclusive Economic Zone, Fisheries Management Area of the Republic of Indonesia (Study of Verdict Number : 03/Pid.Sus.P/2012/Pn.Mdn”, USU Law Journal, Vol.II-Number 1.

[13] Mas Nana Jumena dan Belardo Prasetya Mega Jaya, 2019. IUUFishing Law Enforcement Conducted by Foreign Vessels in the Natuna Sea in the Era of Regional Autonomy", Aura Publishing, Lampung, ISBN: 978-623-211-018-2.

[14] Melly Aida, 2012. "Arrest Countermeasures of illegal fishing which did foreign vessels in Indonesian Exclusive Economic Zone", Fiat Justitia, Law Journal Unila, Volume 5 Number 2 Mei-August.

[15] Muhammad Tasrih, 2014. "Management of fish resources in Indonesian EEZ by the landlocked State according to UNCLOS 1982", Journal of Legal Legal Opinion, Vol. 2.

[16] Susanto Masita, "Law Enforcement of Illegal Fishing in Arafura Sea", University of Hasanuddin Journal, Can be accessed at http://pasca.unhas.ac.id/jurnal/files/3d820644ecf4698c467865141a42 bcdc.pdf.

[17] Usmawadi Amir, 2013. "Law Enforcement of IUU Fishing According to UNCLOS 1982 (Case Study: Volga Case)", Journal of Juro Opinion, Vol. 12, January-April.

[18] Online News, Arief Afrianto, Detik.Com, "Illegal Fishing Forgotten Transnational Crimes, can be accessed online at http:// news.detik .com, accessed on April 27th 2019.

[19] Online News, Jokowi: Indonesia loses IDR 260 Trillion Due to illegal fishing, can be accessed online at https://katadata.co.id/berita/2016/10 /10/jokowi-indonesia-rugi-rp-260-triliun-akibat-pencurian-ikan

[20] United Nations Convention on the Law of the Sea (UNCLOS) 1982 
[21] Law Number 31 of 2004 as amended to the Law Number 45 of 2009 concerning Fisheries.

[22] Law Number 6 year 1996 concerning Indonesian Waters.

[23] Minister of Maritime Affairs and Fisheries Regulation No. 30 Year 2012 concerning Capture Fisheries Business in the Republic of Indonesia's Fisheries Management Area

[24] Regulation of the Minister of Maritime Affairs and Fisheries of the Republic of Indonesia Number 17/PERMEN-KP/2014 concerning the Implementation of the Fishery Supervisory Duties

[25] Presidential Regulation No. 115 Year 2015 concerning the Task Force on Combating Illegal Fishing.

[26] Decree of the Minister of Maritime Affairs and Fisheries Number Kep.50/Men/2012 concerning the National Action Plan for Prevention and Management Illegal Unreported, and Unregulated Fishing Year 2012-2016. 